\title{
SHAKESPEARE'İN III. RICHARD OYUNUNDA RÜYANIN KULLANIMI
}

\author{
Funda Sakaoğlu Eryek ${ }^{1}$
}

\section{Özet}

$\mathrm{Bu}$ makale Shakespeare'in III. Richard oyununda rüyanın kullanımını farklı perspektiflerden inceleyecektir. Shakespeare III.Richard oyununu şekillendirirken dönemin rüyaya bakış açısının ikileminde kalmış; rüyanın doğal bir fenomen ya da doğaüstü bir güç olduğu konusundaki kararsızlığını oyuna yansıtmıştır. Rüyalar; oyun boyunca gerçekleşen olaylara yorum yapmamızı kolaylaştıran unsurlar olmasının yanı sıra, karakterlerin eylemlerini ruhsal açıdan algılamamızı olanak sağlayan güçlü semboller olarak çözümlenebilmektedir. III. Richard'da rüyalar; karakterlerin hırslarını, işledikleri suçları ve günahlarını büyüterek oyunun odak noktasını insanların seçim yapma ve bu seçimleri yaşam içerisinde uygulama kapasitesine doğru yöneltmektedir. Bu makale, III. Richard oyununun trajik yapısı göz önüne alındığında, rüyaların Shakespeare tarafından oyunun içine nasıl kasten yerleştirildiğini anlayabilmek adına klasik ve erken modern dönem rüya teorilerini inceleyecek ve sonrasında Clarence'in, Richard'ın ve Stanley'in rüyalarını doğaüstü inançlar ve insan tabiatının ve deneyiminin parçası olarak değerlendirecektir.

Anahtar kelimeler: Rüya, Shakespeare, III. Richard, Tiyatro, Psikoloji

\section{DREAMS IN SHAKESPEARE'S RICHARD III}

\section{Abstract}

This paper argues the use of dreams from different point of views. While forming the play Shakespeare was in a quandary over whether the dreams were supernatural or natural phenomena and reflected this to his play. Dreams in play can be read as facts that help us to comment the incidents throughout the play and they can be also analyzed as bold symbols which tells us the spiritual implications of the characters' actions. Dreams in Richard III basically sharpen the focus of the play on human by deepening the character's ambitions, crimes and convicted shames. Considering the tragic structure of the play, this paper will examine classical and early dream theories in order to understand how Shakespeare implied the dreams to the play on purpose and will evaluate Clarence's, Stanley's and Richard's dreams as a part of supernatural beliefs and human nature and experience.

Keywords: Dreams, Shakespeare, Richard III, Theatre, Psychology

\footnotetext{
1 Sahne Sanatları Profesyoneli, ORCID ID: 0000-0001-9355-5053, fundasakaoglu@gmail.com
} 


\section{Giriş}

Shakespeare'in III. Richard eseri rüyalara, hayallere ve kehanetlere önemli ölçüde referanslar içerir. John Jowett; III. Richard oyununda "rüya" kelimesinin ve onunla ayn soydan gelen kelimelerin' diğer Shakespeare oyunlarından daha fazla (replik içerisinde yirmi beş kez, düzen açılamasında bir kez) kullanıldığını belirtir (Shakespeare, 2008, s. 52) . ${ }^{2}$ Oyunun içinde üç ana rüya sahnesi vardır; Clarence' ın kendi ölümünü tahmin ettiği rüyası (I. Perde, IV. Sahne), Stanley'in Hasting'in sonrasında gerçekleşecek olan ölümü ile bağlantılı uğursuz rüyası (III. Perde, II. Sahne). Oyunun en öne çıkan rüya sahnesi şüphesiz ki V. Perde, IV. Sahne'deki Richard ve Richmond'un derinden etkilendiği sahnedir. Burada Richard'ın öldürdüğü kurbanlar, rüyalarında kralı ziyaret ederek; 'Umutlarn yok olsun, geber!' (Shakespeare, 2010, s.163) ${ }^{3}$ der. Bu Richmond'a söylediği 'Yaşa ve yücel!'4 (Shakespeare, 2010, s.163) cümlesinin tam tersidir. Görünen odur ki hayaletlerin arzusu, Richard'ın 'Bir at! Bir at verin! Krallı̆̆ıma karşılık bir at!'5(Shakespeare, 2010, s.173) haykırışının ardından savaş alanında Richmond tarafından gerçekleştirilecektir.

Clarence'ın, Stanley'nin ve Richard'ın hayalleri gelecekten izler taşıyor gibi görünse de, bu hayaller aslında erken modern dönemde rüyaların karmaşık durumunu yansitır. Bu nedenle III. Richard oyununda rüyalar doğaüstünün ve psikofizyolojinin keşiştiği noktada durmaktadırlar. Bu belirsiz durum yorumsal bağlamda da bir belirsizlik yaratır. Jowett III. Richard oyununda; 'bazı rüyaların gelecekten haber verdiğini, bazılarmın rüya görenin duygu durumunu yansittığını, bazılarının arasında ise çok az fark olduğunu' (Shakespeare, 2008, s.52) ${ }^{6}$ belirtir. Ancak III. Richard oyununda rüyalar bir motifi tekrar eder çünkü Shakespeare klasik tragedyada bulunan tanrı tarafından gönderilen ve geleceğe dair mesajlar içeren rüyaları, geçmişteki ve gelecekteki durumlarla ve karakterlerin duygu durumlarıyla bilinçli olarak ilişkilendirir. Sonuç olarak okuyucu ve izleyici karakterlerin içsel durumuna, kendi içlerinde yaratıkları trajedilere daha çok odaklanır. Bu durum; rüyaları dışsallaştıran ve doğaüstü güçlere bağlayan klasik rüya görüşünden ziyade rüyaları içselleştiren ve insanla bağdaştıran erken modern dönem rüya görüşünü yansitir.

Geleneksel kehanet öngörülerinin aksine III. Richard oyununda rüyalar, yüce güçler tarafından kontrol edilen olaylar zincirini açı̆̆a çıkarmazlar dolayısıyla olay örgüsünü şekillendirmezler ve değiştirmezler. Karakterler, Shakespeare'in kendi tragedya modeli çerçevesinde özerk bir şekilde ağır ağır kendi felaketlerine ilerlerler; klasik tragedya modelinde olduğu gibi önceden belirlenmiş aksiyon

\footnotetext{
2 William Shakespeare, Richard III, ed. John Jowett, Oxford University Press, Oxford, 2008.

${ }^{3}$ William Shakespeare, III. Richard, Çev. Özdemir Nutku, , s.163.

${ }^{4}$ William Shakespeare, III. Richard, Çev. Özdemir Nutku, s.163.

${ }^{5}$ William Shakespeare, III. Richard, Çev. Özdemir Nutku, s.173.

${ }^{6}$ William Shakespeare, Richard III, ed. John Jowett, s.52.
} 
dizisiyle yüzleşmez ya da metafizik güçler tarafından kontrol edilmezler. Rüyalar; oyunda karakterlerin ruh, beden ve zihin durumlarını yansıtarak, karakterlerinin, korkularının, vicdan azaplarının ve bunların getireceği sonuçların daha iyi anlaşılmasını sağlar. Bu farkındalık onların gerçeğe bakış açısını asla değiştirmez, aksine karakterler kendi yarattıkları yıkıcı ortamda trajik bir biçimde dibe vururlar. III. Richard oyununda rüyalar, karakterlerin trajediyi nasıl yarattığı, bu trajedide nasıl ilerlediği ve trajedilerini nasıl deneyimledikleri noktasında Shakespeare'in odağındadır.

Marjorie Garber, III.Richard oyununda rüyaları 'psikolojik gözlemlere, tarihsel birikimlere...yapısal bütünlüğe, yaratıcı bilinçdışına' (Garber,1974, s.20-21) ${ }^{7}$ bağlasa da Stephan Greenblatt oyunun hayaletlerini 'psikolojik terörün iç içe geçmesine, Makyavelce politikalara ve metafiziğge'8 (Greenblatt, 2001, s.179) bağlar. Yapılan pek çok eleştiri oyunun rüyalarını önemsenmeyen ya da yanlış anlaşılan ilahi rüyalar olarak görürken, diğer eleştiriler Shakespeare'in eserlerindeki ve Erken Modern Dönem eserlerinde olduğu gibi rüyaların gizemli yapısını geçmişe yönelik bir biçimde Freudyen açıdan inceler. Sonuç olarak karakterlerinin, okuyucusunun ve izleyicisinin trajik deneyimleri yeniden şekillendirmeye yardımcı olabilmesi için Shakespeare'in rüyaların Erken Modern dönem rüya anlayışının belirsizliklerinden nasıl faydalandığ 1 ve rüyaların yapısında nasıl kasten oynadığı konusuna yeterince odaklanmazlar.

\section{Erken Modern Dönem Rüya Anlayışı}

Shakespeare'in eserlerindeki rüya kavramını anlamak için öncelikle onun dönemindeki rüya anlayışına göz atmak gerekir. Rüyalar hakkındaki erken modern dönem görüşü antik çağlardan beri süregelen fizyolojik ve kehanet bildiren (ya da doğaüstü) ayrımına dayanırdı. Bu ayrım Yunanlı yazar ve kahin Daldis'li Artemidorus (MS. 2. Yüzyıl) tarafından yapılmıştı. Çığır açan eseri Oneirocritica' da fizyopsikolojik rüyalara 'enhypnion' adını vermiş bu tür rüyaları: 'mevcut durumun bir hatırlatmasi' olduğunu belirterek; enhypnion'ların 'bir anlamı olmayan ve herhangi bir şeyi tahmin etmeyen rüyalar olduğu gibi, yalnızca bir kişi uyurken aktif hale gelen ve irrasyonel bir arzudan, sıradışı bir korkudan, az ya da çok yemek yemekten kaynaklandığının' altını çizmiştir. ${ }^{9}$ (Artemidorus of Daldis, 1975, s.4) Artemidorus, ikinci tür rüyayı 'oneiros' olarak adlandırır. Enhypnion'ların aksine oneiros'ların geleceği yansıttığını belirtir ve bu tarz rüyaların kaynağının doğaüstü güçler olduğunu söyler: 'Oneiros; gelecekte meydana gelecek iyi ya da kötü şeyleri gösteren,

\footnotetext{
${ }^{7}$ Marjorie Garber, Dream in Shakespeare: From Metaphor to Metamorphosis, Yale University Press, New Haven,CN, 1974, s.20-21.

8 Stephan Greenblatt, Hamlet in Purgatory, Princeton University Press, Princeton,NJ, 2001, s. 179.

${ }^{9}$ Artemidorus of Daldis, The Interpretation of Dreams: Oneirocritica, Trans. R.J. White, Noyes Press, Park Ridge, NJ, 1975, s. 4.
} 
zihnin şekilden şekle girdiği bir hareket ya da durumdur.'10 (Artemidorus of Daldis, 1975, s.1-2) Artemidorus'a göre oneiros ya tanrı tarafından gönderilmiştir ya da ruh tarafından üretilmiştir, ki bu durumda da Tanrı'nın insan ruhuyla etkileşim halinde olduğu göz önünde bulundurulursa, ikinci seçenekte dahi bu tarz rüyaların tanrı tarafından gönderildiği yadsınamaz bir gerçektir. ${ }^{11}$ (Artemidorus of Daldis, 1975, s.1-6) Romalı şair Claudian muhtemelen Lucretius'un De Rerum Natura adlı eserindeki bir pasajdan ( $\mathrm{ki}$ bu pasajın çevirisi Shakespeare'in Romeo Juliet'inde (1595) ve Chaucer'in Parlement of Foulys' in de (1380) de bulunmaktadır) etkilenerek Artemidorus'un enhypnion adını verdiği tarzdaki rüyaları; avcıların genelde av rüyası gördügüu, hakimlerin genelde dava rüyası gördüğü, aşıkların ise genelde aşk rüyası gördüğü düşüncesiyle açılamıştır. 12 (Presson, 1967, s. 239-256) Rüyaların doğal ve doğaüstü şeklinde iki kategoriye ayrılması; Hipokrat (De Victu - On Regimen adlı metninde), Herophilius, Galen, Averroes, Cardano ve St.Augustine gibi kuramcıların eserlerinde de yer alır. Yazdıkları ile Orta Çăg ve Erken Modern Dönem teorilerini ve Dante ve Chaucer gibi yazarları etkileyen Romalı yazar Macrobius da, Artemidorus'tan, Neo-Platonik ve Stoik felsefeden etkilenmiş ve rüyaları aynı iki kategori ile sınıflandırmıştır. ${ }^{13}$ (Macrobius, 1952, s. 42-46)

Klasik Antik Çă̆'da rüyaların Tanrı tarafından ya da diğer doğa üstü güçler tarafından gönderilmesi ihtimali hiçbir zaman açı ve seçik bir biçimde antik felsefelerle rekabet edebilecek durumda değildi. Örneğin Stoacılık rüyalar da dahil olmak üzere her türlü ilahi olana ulaşma öğretisini kabul ediyordu. ${ }^{14}$ (Harris, 2009, s.170) Dönemin yaygın kültürel görüşünün bir sonucu olarak rüyaların Tanrı tarafından gönderildiği ve kehanetler içerdikleri Aeschylus gibi pek çok antik trajedide yer almaktaydı. Greenblatt'ın da belirttiği üzere Antik Yunan ve Roma oyunları 'tarihi gerçekliğin bir katmanı olarak' hayaletleri, kehanetleri, gelecekten haber veren rüyaları ve lanetleri içermekteydi. ${ }^{15}$ (Greenblatt, 2001, s.165)

Klasik Antik Çağ, Orta Çağ'a ve Rönesans'a da aktarılan rüyalar düşüncesine dualistik bir bakış açısı yarattı. Orta Çăğ'1 etkileyen kuramcı Thomas Aquinas rüyaların sebeplerini içsel ve dışsal sebepler olmak üzere ikiye ayırdı. Aquinas'a göre içsel sebepler; zihinde, bedende ve ruhta vücut bulurken dışsal sebepler çevresel faktörlerin yanı sıra ilahi ve şeytani güçlerden kaynaklanmaktaydı. ${ }^{16}$

\footnotetext{
${ }^{10}$ Artemidorus of Daldis, a.g.e. , s. 1-2.

${ }^{11}$ Artemidorus of Daldis, a.g.e. , s. 1-6.

${ }^{12}$ Robert K. Presson, 'Two Types of Dreams in Elizabethan Drama, and Their Heritage: Somnium Animale and the Prick-of-Conscience', Studies in English Literature, Volume 7 No:2, Spring 1967, 239-256.

${ }^{13}$ Macrobius, Commentary On The Dream of Scibio, Trans. And Ed. W.H.Stahl, Columbia University Press, New York, 1952, s. 42-46.

${ }^{14}$ William V. Harris, Dreams and Experience in Classical Antiquity, Harvard University Press, Cambridge, 2009. S.170.

${ }^{15}$ Stephan Greenblatt, A.g.e., s. 165.

${ }^{16}$ Manfred Weidhorn, Dreams in Seventeenth-Century English Literature, Mounton\&Co, Paris, 1970, s.32-33.
} 
(Weidhorn, 1970- s.32-33) Edebiyatta bu dualistik düşünce özellikle Orta Çağ Düş Şiirinde filizlenmeye başladı. ${ }^{17}$ (Helen Philips ve Nick Havely, 1997, s.5) Bu teoriler Shakespeare'in döneminde şekillenmeye başladı; örneğin Thomas Hill'in The Moste Pleasaunte Arte of the Interpretaction of Dreames (Rüyalar En Zevkli Yorumlama Sanatı) 1559 yılında yayımlandı. Peter Holland'a göre Hill'in eseri 'Rönesans döneminde yazılmış rüya kuramına dair en önemli girişimdir.'18 (Holland, 1999, s.142) Hill eserinde Artemidorus, Aristoteles, Hipokrat ve Galen'in rüya teorilerine değinir ve Artemidorus'un rüya sinıflandırmasının bir tekrarını yapar (16. yüzyılda Artemidorus'un Oneirocritica adlı eserini Latince, Fransızca, Almanca ve İtalyanca olarak okumak mümkündü İngilizce'ye ise 1606 yılında R. Wood tarafından çevrildi) Hill'e göre; rüyalar bedenin mevcut arzularını ve ilgisini gösteren ve gelecek olayları anlatmaktan yoksun rüyalar olan 'faydasız rüyalar'(enhypnia) ve gelecekte yaşanacak olayları bildiren ve doğaüstü güçler tarafından gönderilen 'gerçek rüyalar' olmak üzere ikiye ayrılmaktaydı. ${ }^{19}$ (Hill, 1576, A2r-D7r)

Klasik Antik Çağ düşünce biçiminin Erken Modern dönemde biraktığı izler elbette pek çok ideolojinin yeniden yorumlanmasını da beraberinde getiriyordu. Shakespeare'in döneminde Klasik Antik Çağ'ın aksine rüyalar açı ve seçik bir biçimde batıl ve muğlak bir inanç ile ilişkilendirilmeye başlanıyordu. Klasik Antik Çağ'da rüyaların doğal ve doğaüstü olarak ayrımı evrensel düzlemde hiçbir zaman yerini ilahi ve gerçek rüyalar ayrımına bırakmadı. Erken Modern Dönem rüya görüşleri fizyopsikolojik ve materyal sebeplere odaklanarak ve şeytanın işin içine karıştığını göz önünde bulundurarak rüyaların Tanrı tarafından gönderilen bir mesaj değil aldatıcı potansiyelini vurguladı. ${ }^{20}$ (Parman, 1991, s.40-43) Bu konuda giderek artan şüpheciliği mucizelerin son bulduğu görüşünü benimseyen Protestan inancı da körükledi. ${ }^{21}$ (Shaw, 2006, s.1-50) Erken Modern Dönem İngiltere'sinde rüyalar antik dönemden daha problematik bir fenomendi. Rüyaları kehanetler ve doğaüstü güçlerle ilişkilendiren Hill bile okuyucusuna profesyonel rüya tabircilerine güvenmeleri gerektiği konusunda öğüt veriyordu; 'az sayıda papaz rüyaların gerçek doğasını anlayabilir, daha azı ise onlar anlamlandırabilir ve ardındaki gizemi açı̆̆a çıkarabilir.' 22 (Hill,1576, s. A3v) Dönemin yazarları, Hipokrat, Aristotoles ve Galen yazıtlarından etkilendikleri için rüyaların mizacın bir eğilimi olduğu ve

17 Helen Philips \& Nick Havely(ed.), Chaucer's Dream Poetry, Longman, London - New York, 1997, s. 5.

18 Peter Holland, 'The Interpreation of Dreams in the Renaissance' Reading Dreams: The Interpretation of Dreams from Chaucer to Shakespeare, Ed. Peter Brown, Oxford, London, 1999 s.142.

${ }_{19}$ Thomas Hill, The Most Pleasaunte Arte of the Interpretacion of Dreames, Thomas Marsh, 1576, A2r - D7r.

${ }^{20}$ Susan Parman, Dream and Culture: An Anthropological Study of the Western Intellectual Tradition, Praeger, New York, 1991, s. 40-43.

${ }^{21}$ Jane Shaw, Miracles in Enlightment England, Yale University Press, New Haven, 2006, s.150 .

${ }^{22}$ Thomas Hill, A.g.e. , Mühür A3v. 
uyanık olduğumuz zamandaki düşüncelerimizin yeniden uyanışı oldukları görüşlerini benimsemeye başladılar. Örneğin Thomas Wright, 'hazlarımızın bolluğunu rüyalarla kanıtlarız' der ve şöyle devam eder: 'Bu rüyalar hayal gücüne tutunan ruhlar tarafindan görülür. Tabiatlarn gereği saf ya da müstehcen, sicak ya da soğuk, fazla ya da az (bu çeşitlilik bedenin hazzına göre çeşitlilik gösterir) olabilirler'23 (Wright,1604, s. Flr) Regina Scot ise şöyle der: 'bazı rüyalar öfkenin, ağırkanlılığın, melankolinin ya da kanamanın bir sonucu olarak görülürken bazıları ise aşkın, aşırn yemek yemenin, açlığın, susuzluğun...vb sonucu olarak görülür.'24 (Scot, 1886, s.144)

Tanrı tarafından gönderilmiş rüyaların ve ilahi rüyaların doğruluğu erken modern dönemde Klasik Antik döneme nazaran güçlü ve sistematik bir biçimde daha fazla tartışılmış olmasına rağmen, bu fikirlerin ortadan kaybolduğuna dair yanlış bir düşünceye kapılmamak gerekir. Aslına bakılırsa bu inanç daha az eğitimli ve dindar kesimde varlığını sürdürmeye devam etti. Pek çok erken modern dönem insanına göre gerçeğe uygun ve doğaüstü rüyaların kanıtları İncil'de bulunmaktayd1. ${ }^{25}$ (Hill,1576, s. A3r)

Bu bağlamda hekim Andre Du Laurens; 'Tanr tarafindan gönderilen rüyalarn gelecekte olacak şeyleri zaman zaman insanlarm aklına soktuğunu ve rüyayı gören kişi için büyük gizemler yarattı̆̆ıı' belirtirken, papaz ve yazar Thomas Walkington ilahi rüyaların 'yaklaşan olayların habercileri olduğunu ve bunların 'yanlış illüzyonların' tam zıttı olduğunu' söylemiştir. ${ }^{26}$ (André Du Laurens, 1599, s.100) Bunun haricinde çeşitli popüler inanışlara göre sabahları, dolunayda, gündönümlerinde ve Noel gibi özel günlerde görülen rüyaların daima önemli ve doğru olduğu kabul edilmiştir. ${ }^{27}$ (Hill, 1576, s. Clv, E2r) Tüm bu görüşler rüyaların psikolojik mi yoksa doğaüstü mü olduğu tartışmasını ateşledi. Mucizeler gibi rüyalarda Reformasyon sonrası İngiltere'sinde Protestan inancının mucizelerin sona erdiği savını kuvvetlendirmek için siyası amaçla kullanılmış ve bu da Shakespeare'in döneminde rüyaların statüsünün belirsiz kalmasına yol açmıştır. Alexandra Walsham'ın açıçca belirttiği gibi hem Protestanlar hem de Katolikler mevcut durumları kendi çıkarına göre kurnazca kullanmış, kendi çıarına uymayan yorumları ise göz ardı etmiştir. 28 (Walsham,1999, s.237-238) Carole Levin Protestanların ilahi rüyalara inanmay1 sürdürdüklerini, John Foxe'un Acts and Monuments (1563) eserinde Tanrı tarafından gönderildiğine inanılan rüyalarla dalga geçmesine rağmen, 'bu rüyalar gelecekte şehit olacak kişilerin rüyalarıysa büyük bir ciddiyetle yaklaşılması gerektiğini' öğütlediğinin

${ }^{23}$ Thomas Wright, The Passions Of The Minde in General, Valentine Simmes and Adam Islip for for Walter Burre and Thomas Thorpe, London, 1604, Mühür Flr.

${ }^{24}$ Reginald Scot, The Discoverie of Witchcraft, Being A Reprint of the First edition Published in 1584, ed.Brinsley Nicholson, Elliot Stock, London, 1886, s.144.

25 Thomas Hill, A.g.e. , Mühür A3r.

${ }^{26}$ André Du Laurens, A Discourse of the Preservation of the Sight, Trans. Richard Surphlet, Felix Kingston for Ralph Jacson, London, 1599, s. 100.

${ }^{27}$ Hill, A.g.e., Mühür Clv, E2r.

28 Alexandra Walsham, Providence in Early Modern England, Oxford University Press, Oxford, 1999, s. 237-238. 
altını çizmiştir. ${ }^{29}$ (Levin, 1563, s.64-66) Sonuç olarak rüyaların bedensel mi yoksa doğaüstü sebeplerden kaynaklandığı tartışması, Erken Modern dönem yazarlarının rüya tabirine dair düşünceleri ile birleşmesi, Shakespeare'e bolca dramatik malzeme sağlamıştır. Böylece III. Richard oyununda Shakespeare, trajedinin politik yüzü, zahiri metafizik yönü ve karakterlerin rasyonel düşünce modları ve çıkarımlarına ket vuran mistik deneyimleri arasındaki tansiyonu arttırmıştır. Oyunda, rüyaların belirsiz tabiatı, karakterlerin trajik sorumluluğun bedensel mi yoksa spiritüel bir perspektiften mi yaklaşılması gerektiği sorusuna yanıtlamaya yardımcı olmuştur. Dramatik bağlamda güçlü anlar bir araya getirildiğinde metnin içerisinde farklı seküler ve dini anlamları içinde barındırdığını görmek mümkündür. Bunun etkisi sonucunda da trajik deneyimin kapsamı genişlemiş ve insan tabiatının odağı keskinleşmiştir.

\section{Richard Oyunundaki Rüyaların Yeniden Yorumlanması}

III. Richard İngiliz tarihindeki kötü bir üne sahip krallardan biridir. Yeğenleri, karısının eski kocası ve eski kayınpederinin ölümünden ve daha pek çok cinayetten suçlanmaktadır. Richard bu cinayetleri tahtı ele geçirmek ve elinde tutmak adına işlemiştir. Yaklaşık iki yıl tahtta kalan ve değerli tarihi belgelere göre başarılı bir yönetime imza atan III.Richard'ın kötü şanının nedeni William Shakespeare'in III. Richard oyununda çizdiği III.Richard portresidir. Oyun Richard'ın baş düşmanı olan Tudor hanedanlığının yükseliş döneminde yazılmıştır. Yararlandığı tarihi kaynaklar ve dönemin siyasi ortamı göz önünde bulundurulduğunda Shakespeare bir kahramandan ziyade insanların gözüne daha da batacak olan bir canavar yaratmak zorundaydı. Bu nedenle Shakespeare'in metninde pek çok abartı ve tutarsızlık bulunmaktadır.

Shakespeare Richard'ın ünlü rüyaları üzerinde çalışırken, kullandığı kaynaklar açısından seçici davranmıştır. Geoffrey Bullough'un belirttiği üzere, Edward Hall'ın Union of the Two Noble and Illustrate Famelies of Lancastre and Yorke (1548) eserinde tanımladığı gibi Richard'a 'onu çekip sürükleyen türlü türlü imgelerin yer aldığı berbat ve korkunç' rüyalar vermek yerine, Shakespeare muhtemelen ilhamını ya rüyalar için 'Richard tarafindan cinayete kurban giden hayaletlerin vakitsizce mezarma gönderildiğini' savunan The Mirror for Magistrates (1559)'den ya da anonim eser The True Tragedy of Richard III (1588-92? / Baskı Y1lı: 1594)'dan almış ya da kendi eseri için her ikisinden de beslenmiştir. ${ }^{30}$ (Bullough, 1977, s.247) The True Tragedy'de Richard: 'Uyuduğumda / Uyandı̆̆ımda / Her ne yaparsam yapayım/ Krallık yolunda katlettiklerim / Gelir intikam için/' bilgisini okuyucuyla paylaşmadan önce 'Hayatın cehennemi...Krallı̆̆ın tacında

${ }^{29}$ Carole Levin, A.g.e., s. 64-66.

${ }^{30}$ Geoffrey Bullough, Narrative and Dramatic Sources of Shakespeare,Volume 3, Routledge and Kegan Paul, London and Henley, 247. 
asılı' der. ${ }^{31} .32$ (Bullough, 1977, s.317-345) The True Tragedy yalnızca rüyay1 okuyucuya ve izleyiciye rapor ederken, Shakespeare kendi oyununda daha büyük dramatik bir etki yaratmak için rüyayı görselleştirmeyi tercih etmiştir. Kaynaklarından yola çıkarak iki karakter arasındaki kontrastı derinleştirmek için Richmond'un rüyasını uzatmayı tercih etmiştir. Shakespeare'in bu kısmı yeniden yazması hem karakterleri hem de seyircileri için önemli anların iç görüsünü yansıtmak adına kasten uyarlanmıştır. Sonuçların bu eserlerden çıkarıldığı ama Shakespeare tarafından radikal bir biçimde değişikliğe uğratıldığı aşikardır.

Richard'ın, Clarence'ın ve Stanley'in rüyaları kehaneti içeren doğası, uyandırdığı doğaüstü intikam hissi, ilettiği determinizm, oyundaki lanetlerinin geniş çerçevesi ve III. Richard oyunun düzene sokan önseziler, klasik Senaca trajedisinden izler taşımaktadır. Aslında Richard'ın kötü adam olması ve hırsına bağlı olarak şeytanla olan ilişkilendirilmesi önceden belirlenmiştir. İlahi kaynaktan alınan onaylar ve kınamalar genellikle politik hilelerden ayrılamayacak durumdadır.

III. Richard iyi yürekli olarak adlandırılacak bir kral değildir. Oyun boyunca gerek Richard'ın kendisi, eylemleri ve sözleriyle gerek oyunda yer alan diğer karakterler Richard'a ettikleri beddualarla bu durumu açıkça dile getirir. Bu nedenle hem Richard'1 sahnede izleyen seyirciler hem de oyun metnini okuyanlar Richard'ın kişiliğinin özünde kötülük yattığını anlamakta gecikmezler. Çünkü Richard'ın gücü elde etmek adına yapmayacağı hiçbir şey yoktur.

III. Richard oyunu boyunca, oyunun başkahramanının düşüşünün, özellikle krallara ve kral olacaklara karşı işlediği suçlara karşılık ödediği bir bedel olduğuna dair güçlü bir önerme vardır. Erken Modern dönemde hükümdarın Tanrının yeryüzündeki temsilcisi olduğuna inanıldığı göz önünde bulundurulursa, Shakespeare'in oyunu kral katilliğinin kaçılmaz sonucunun ilahi bir cezası olduğu fikrini akıllara getirmektedir. Bununla birlikte insan hatalarının cezalandırıcısı olarak Tanrıların temsili ve klasik dramada bulunan Hübris Shakespeare tarafından miras olarak devralınmıştır. Örneğin Aeschylus'ın Persler adlı tragedyasında Zeus; 'düşüncelerin cezalandıncısı' ve 'fazla kibirli'33 olarak nitelendirmiştir. Muhtemelen Shakespeare'in oyununda en güçlü ilahi müdahale hissiyatı Richard'a yöneltilen sayısız bedduadan kaynaklanır. VI. Henry'nin ölümünün ardından yas tutan Lady Anne Richard'1 'cehennem elçisi' olarak tanımlar ve şu sözlerle Richard'a beddua okur:

“Lanet olsun, bu yaraları açan ele!

${ }^{31}$ Geoffrey Bullough, Narrative and Dramatic Sources of Shakespeare, Volume 3 içinde 'The True Tragedy of Richard III' s.317-345.

${ }^{32}$ Geoffrey Bullough, Narrative and Dramatic Sources of Shakespeare,Volume 3, Routledge and Kegan Paul, London and Henley, 247.

33 Aesychylus, The Persians, Trans. And Ed. Antony J.Podlecki, Bristol Classical Press, 1991, 1.827-828. 
Lanet olsun, bunu yapmaya Yüreği elveren Yüreğe!

Lanet olsun, kanını akıtanın soyuna sopuna!

Seni öldürerek bizi perişan eden

O iblisin başına daha korkuncu gelsin.

Ona okuduğum belayı, yılanlara, örümceklere, kurbağalara,

Zehirli sürüngenlere okumaya dilim varmaz!

Bir gün çocuğu olursa, eksik, vakitsiz gelsin dünyaya,

Dilerim, çarpuk çurpuk bir ucube olsun,

Ödü patlasın anasının, bakınca doğurduğu canavara;

Dilerim, kötü ruhlu babasının mirasçısı olsun!

Eğer bir gün evlenirse, öldüğünde,

Onun karısının çekeceği acı kat kat beter olsun

Genç efendimin ve senin ölümünle çektiğim acıdan (Shakespeare, 2010, s.12).”34

Henry'nin dul eşi Margaret da Anne'in beddualarını kopyalayarak Richard'1 'krallığı cehennem olan bir şeytan' olarak tanımlar ve şu sözleri ekler: 'Tanrı beter etsin mutsuzluğunu! İtibarın, saltanatın, tahtın hepsi benimdir aslında!' Margaret'ın bedduaları Edward Hall'ın güncesinde de bulunan rüyanın yani oyunda Richard'ın göreceği kâbusun da bir imasıdır:

“Dur köpek! Kulaklarını aç da beni dinle!

Sen şu zavallı dünyadaki barışın baş belası,

Senin için dilediğim belalardan

Daha büyüğü varsa yüce Tanrı' nın elinde

Günahların iyice azana kadar beklesin

Sonra da olanca gazabını yağdırsın üzerine!

Vicdan azabı hiç durmadan kemirsin içini!

Dilerim, yaşadığın sürece

En yakın dostların hain görünsün gözlerine!

En büyük hainleri, en yakın dostların bilesin!

O katil gözlerine uyku girmesin.'

Girse de cehennem zebanileri gör düşünde,

${ }^{34}$ Willam Shakespeare, III. Richard, Çev. Özdemir Nutku, İş Bankası Kültür Yayınları, İstanbul, 2010, s. 12. 
Sana azap verecek işkenceler girsin düşlerine!

Kötü cinlerin kalıpladığı erken doğmuş yabandomuzu

Seni doğuştan doğanın kölesi, cehennem fırlaması.

Seni doğuran zavallı ananın yüz karası!

Baba tohumunun utanç veren dölü,

Beş para etmez, rezil paçavra, aşağıllı... (Shakespeare, 2010, s.34)"35

Oyunun bu kısımları göz önünde bulundurulduğunda, Richard'ın rüyası daha yüksek bir yargılamanın ve intikamın bir ifadesi, son mağlubiyeti ise cezanın doruk noktası olarak görülebilir. V. Perde IV. Sahnede yer alan düzen açıklamasında da belirtildiği üzere hayaletlerin varlığ1 onların hayal ürünü olmadığının ve gerçekten var olduklarının okuyucuya ve izleyiciye kanıtlar niteliktedir. Bununla birlikte göze çarpan bir diğer önemli nokta rüyaların Buckingham'ın da belirttiği üzere 'zavall ruhların yapılan yanlışların cezasın ödeyeceği'(Shakespeare, 2010, s.156) ${ }^{36}$ Ölü Ruhlar Yortusu'nda görülmesidir.

Richard'ın ve Richmond'un rüyalarının doğaüstü rüyalar olduğu; Richard'ın şeytani, Richmond'un kurtarıcı olduğu dikkatlice kurgulanan alegorik bir kontrast ile beslenmektedir. Bu dikotomi muhtemelen oyununun temelinin ahlak oyunu geleneğine yaslanmasından doğmaktadır: Richard karakteri, güçlü bir biçimde Orta Çă̆ ahlak oyunlarında gördüğümüz Kötülük stereotipi ile bağlantılıdır. Richard bu göndermeyi oyunda 'Kötülüğü canlandıran soytarı gibi çift anlamda kullanıyorum sözcükleri'37(Shakespeare, 2010, s.77) ile desteklerken bir yandan da taşıdığ1 hançerle bu göndermeyi destekler. 38 (Shakespeare, 2010, s.78) Richard ve Richmond arasındaki kontrast öncelikle en çok Richmond'In kampında, sonrasında ise Richard'ın kampının savaşa hazırlandığı V. Perde IV. Sahne'de belirginleşir. Oyun boyunca Richard'a yöneltilen uğursuz lanet ve kehanetlerin aksine Derby Richmond'a şöyle der:

'Kahraman Richmond, başardın üstüne düşeni,

Kanıtladın kendini!

Ne zamandır gasp ettiği krallık tacını

Çekip aldım o zavallı kanlı zorbanın cansız başından.

Bu senin hakkın, al onu, sür keyfini,

\footnotetext{
35 Willam Shakespeare, a.g.e., s. 34.

36 William Shakespeare, a.g.e., s. 156.

37 William Shakespeare, a.g.e., s.77.

38 William Shakespeare, a.g.e., s.78.
} 
Hakkını ver, bil değerini. ${ }^{39}$ (Shakespeare, 2010, s.174)

Richmond ise askerlerine; 'Tanri'nın onlardan yana olduğunu' ve 'Kutsal ermişlerin dualarının ve haksızlığa uğramış kurbanların ruhlarının yüksek burçlar gibi önlerinde durup onları koruyacă̆ını' belirtir. ${ }^{40}$ (Shakespeare, 2010, s.168) Bu zeminin üstüne, hayaletlerin uyku halindeki iki baş karaktere ilettikleri mesajlar ve düzen açıklamalarında Richard ve Richmond'un aynı sahne olmasının şart koşulması, özellikle sahne performansını doruk noktasına ulaştırır. Pratikte hayaletler her iki karaktere de dönüşümlü olarak seslenirken, şeytan Richard ve kurtarıcı Richmond arasındaki dikotomi buna sembolik bir boyut katar.

Oyunun rüyalarının doğaüstü olarak okunması Senaca öç trajedisinden izler taşımaktadır. Russ MacDonald'ın belirttiği gibi: 'Elizabeth dönemi insanlar Seneca oyunlarm otomatik olarak kan, öç, şiddetli ölüm ve doğaüstü güçlerle ilişkilendirmişlerdir.' ${ }^{41}$ (McDonald, 2002, s.25) Shakespeare'in Senaca trajedilerinden etkilenmesi dolaylı bir şekilde Thomas Legge'in Latince oyunu Richardus Tertius (1580)'den kaynaklanmış olabileceği gibi, direkt biçimde Jasper Heywood'un Seneca Trajedilerinin çevirilerinden de kaynaklanmış olabilir. ${ }^{42}$ (Burrow, 2013, s.185) William Harris; 'Romalı oyun yazarlarmın Stoik yaklaşımın teorik olarak rüyalarn tahmin edilebilir olduğunun altını çizdiğine dair bir eğilimi olduğunu belirtmesine rağmen Seneca'nın konudan kaçındığııı' belirtir. ${ }^{43}$ (Harris, 2009, s.192)

Ancak III. Richard oyununda Shakespeare yalnızca doğaüstü güçler tarafından kışkırtılan ya da doğaüstü güçlerin etkisi altında kalan bir trajedi modeli çizmez, aynı zamanda insan tabiatına ve psikolojisine güçlü bir vurgu yaparak metafizik çerçevesini dengeler. Bu nedenle rüyalar daha karmaşık ve zaman zaman şaşırtıcı bir hal alır. Oyunda rüyalar daha yüksek ahlaki ve spiritüel bir değerin parçası gibi görünseler de kimi zaman da korkuların ve anıların açı̆̆a çıkmasının bir ürünüdürler. Bu; güçlü bir biçimde, I. Sahne, IV. Perde'de Clarence'ın kendi ölümü hakkında gördüğü kabusta görülür:

\footnotetext{
“Kale'den kaçmış, denize açılmışım,

Burgonya'ya yelken açmışım,

Kardeşim Gloucester yanımda,

Kamaradan çıkıp yürüyelim demiş bana.
}

\footnotetext{
${ }^{39}$ William Shakespeare, a.g.e., s.174.

${ }^{40}$ William Shakespeare, a.g.e., s.168.

${ }^{41}$ Russ McDonald, 'The Language of Tragedy', The Cambridge Companion to Shakespearean Tragedy, Cambridge University Press, 2002, 25.

42 Colin Burrow, Shakespeare and Classical Antiquity, Oxford University Press, Oxford,2013, s. 185.

${ }^{43}$ Harris, a.g.e., s.192.
} 
Oradan İngiltere'ye bakıyoruz;

York ve Lancaster savaşlarında

Başımızdan geçen binlerce acı olayı anıyoruz.

Güvertenin kaygan tahtalarında yürürken

Gloucester dengesini kaybediyor birden

Onu tutayım derken,

Bana çarpıyor, ben de yuvarlanıyorum

Okyanusun azgin dalgalarına.

Aman Tanrım, ne zor şeymiş boğulmak diye düşünüyorum,

Ne korkunç uğulduyordu sular kulaklarımda!

Ne çirkin ölüm sahneleri geçti gözlerimin önünden!

Binlerce gemi enkazı, balıkların didiklediği insan cesetleri,

Külçeyle altın, kocaman çapalar, yığınla inci,

Paha biçilmez mücevherler, taşlar

Dağılıp saçılarak denizin dibini boylamışlar.

Bazıları ölülerin kafataslarına yerleşmiş,

Oyuk göz deliklerinde 1şıl ışıl parlıyorlar

Küçümsercesine gözleri;

Balçık tabana dağılan mücevherler

Kemiklerle alay ediyorlardı sanki." 44 (Shakespeare, 2010, s.41)

Rüya farklı kısımlara ayrılır ve Clarence rüyasında boğulmasının ardından kendini yer altı dünyasında bulur. Bu yeraltı dünyasında Warwick ve Prens Edward da dahil olmak üzere yanlış yapacağı kişilerle karşılaşır:

“Derken, ruhumdaki asıl fırtına başladı!

Ozanların şiirlerindeki o asık yüzlü sandalcının teknesiyle

O gamlı ırmaktan geçtik sonsuz karanlıklar ülkesine.

Benim yabancılık çeken ruhumu ilk karşılayan

Anlı şanlı kayınbabam Warwick oldu.

Yüksek sesle seslendi: “Bu karanlıklar ülkesinde,

Yalan yere yemin eden Clarence'e ne ceza verilecek?" dedi,

${ }^{44}$ William Shakespeare, a.g.e., s. 41 .

Uluslararası Sanat ve Estetik Dergisi Yıl: 4, Sayı: 7, Aralık 2021 
Ve gözden kayboldu birden.

Sonra meleğe benzer bir hayalet belirdi;

Işıldayan saçları kana bulanmıştı,

Çı̆̆lığa benzer bir sesle, "Clarence geldi" diye haykırdı,

"Dönek, vefasız, yalancı Clarence geldi...

Tewksbury'de, savaş alanında sendin beni hançerleyen,

Yakalayın onu ifritler, acımayın, işkence edin ona.

Derken bir sürü ifrit korkunç çığlıklarla üşüştü başıma.

İşte o sırada titreyerek uyandım, bir süre ayılamadım,

Hâlâ cehennemde olmadığıma inanamadım

O denli ürkütücüydü bu kâbusun etkisi"45 (Shakespeare, 2010, s.42)

Clarence'ın rüyasının faydasız mi, geleceği bildiren mi, doğaüstü mü yoksa psikofizyolojik mi olduğu tam olarak net çizgilerle belirlenemese de Clarence'ın akıl sağlığının önceki işlediği suçlardan (Henry VI / III. Bölüm) ve dolayısıyla suçluluk duygusundan etkilendiği aşikardır. Seneca öç trajedisi geleneğinden etkilenmesinin yanı sıra Shakespeare'in Clarance'in rüyasını yaratmasındaki bir başka neden; estetik ve dramatik etkiyi arttırmak gibi görünmektedir. Pagan bakış açısının beslediği güçlü tasvirler korku duygusunu büyütürken, Hristiyan alt metin ile birlikte Clarence'ın suçluluk duygusu karakterin trajik eylemine vurgu yapar ve çektiği fiziksel ve ruhsal acının bir temsiline dönüşür.

Garber; Clarence'ın 'ikaz eden' ve 'kehanette bulunan' rüyasının yapisal ve psikolojik önemine dikkat çeker. ${ }^{46}$ Clarence rüyasını anlattığı sahnede öldürülse bile rüyayı doğaüstü ya da kehanette bulunan olarak tanımlamak problematiktir. Aslında Clarence' in rüyası tam olarak olayların oluş sırasını tahmin etmez daha da önemlisi Clarence'ın kafası şarap fıçısına sokulsa bile, kendisi boğularak değil Richard'ın tuttuğu katiller tarafından hançerlenerek öldürülür. Clarence'ın ölümü bağlamında bakıldığında ise Richard'ın rüyada tökezlemesi fiziksel durumundan ziyade, ahlaki çöküntüsünün bir sembolü olarak okunmalıdır. Bu bilgiler elbette rüyanın yansıttığı gerçekler olduğunu değiştirmez çünkü rüya Richard'ın hain doğasını yansıtır ve bu özelliğinin altını çizerek oyunun tehlikeli çehresini yansıtır.

III. Richard oyununda önemli trajik deneyimlerden biri Richard'ın suçlu vicdanının temsili ile gerçekleşir. Vicdan kavramı hem dinsel hem de psikolojik çağrışımları içinde barındıran bir kavram olduğu için Shakespeare bu durumu kendi çıkarı için kullanır. Richard'ın yükselişine ve düşüşüne eşlik eden dini bir

45 William Shakespeare, a.g.e., s.42.

46 Garber, a.g.e. , s. 21-25. 
motif olmasının yanı sıra, metin karakterin tutkuları, motivasyonları ve olayları karşı verdiği zihinsel tepkileri de içinde barındırması bakımından Garber tarafından 'ilk gerçek psikolojik oyun' olarak kabul edilir. ${ }^{47}$ (Garber, 1974, s.88)

Oyunun doğaüstü ve psikolojik boyuta yaptığı çift yönlü vurgu V. Perde IV sahnede karakterin vicdanen acı çekmesi ile daha da derinleşir ve sonrasında hayaletlerin sahne üzerinde görünmesiyle doruk noktasına ulaşır:

“Ah korkak vicdanım bir türlü rahat bırakmıyor beni!

Mavi yanıyor ışıklar. Vakit tam gece yarısı.

Titriyor her yanım, soğuk terler döküyorum.

Neden korkuyorum ki? Kendimden mi?

Burada başka kimse yok ki.

Richard, Richard'1 sever; yani ben benim.

Bir katil mi var burada? Hayır... Evet, ben varım ya.

Kaç öyleyse. Ne, kendimden mi?

Bir nedeni olmalı... Yoksa intikam mı?

Kendi kendimden mi? Olmaz, ben kendimi severim.

Niye sevecekmişim? Hayrım mı dokundu kendime?

A, hayır, yaptıklarımdan ötürü kendimden nefret ediyorum!

Alçağın biriyim ben; yok, hepsi yalan, alçak değilim.

Akılsız, iyi şeyler söyle kendin hakkında.

Dalkavukluk etme, budala.

Vicdanımin binlerce dili var,

Her biri başka bir öykü anlatır;

Hepsi de beni suçluyor alçak diye.

İftira, yalan yere yeminin dik âlâsı;

Cinayet, cinayetin en kanlisl;

Her dereceden her türlü günah,

Yığılmış hepsi, mahkemede,

"Suçlu, suçlu" diye haykırıyorlar.

Bir umutsuzluk çöküyor üstüme.

Beni seven tek bir yaratık yok;

${ }^{47}$ Garber, a.g.e. , s.88. 


\author{
Ölürsem kimse acımayacak bana: \\ Ben bile kendime acımadiktan sonra, \\ Başkaları niye acısın ki? \\ Öldürdüğüm bütün o insanların hayaleti \\ Çadırıma geldi sanki; \\ Yarın Richard'dan intikam almak için \\ Tehditler savurdu hepsi."48 (Shakespeare, 2010, s.166)
}

Richard'ın parçalı konuşmaları zihninin durumunu yansıtan bir ayna niteliğindedir: tahta geçmesine engel olabilecek herkesi öldürerek kendisini yalnızca politik bir kriz içerisinde bulmaz aynı zamanda varoluşsal bir kriz içine de girer. $\mathrm{Bu}$ konuşma Richard'ın trajedisinin en belirgin biçimde açığa çıktığı yerdir, çünkü geç de olsa neyi yanlış yaptığının farkına varmıştır ve artık hareketleri ile vicdanını bağdaştıramaz ve çektiği vicdan azabını bastıramaz durumdadır. Clarence'in görüsü gibi, Richard'ın kâbusu da vicdan azabından kaynaklanan bir rüyadır ve onu korku tarafından esir düşürülmüş ve bu yüzden insanlara korku salan birine dönüştürür. Hayaletlerin Shakespeare tarafından sahnede gösterilmesi işlenen suçun yarattığı vicdan azabının seyirciler ile paylaşılmasını ve Richard'ın suçlu vicdanının intikam duygusu ile su yüzüne çıkmasına sebep olur. Buradaki sebepsonuç ilişkisi yenilgisini oneiros bağlamında yenilgisini önceden haber vermek için kullanılmamış aksine ölümüne sebebiyet verecek olayları özetleyerek seyircinin Richard'ın eylemlerini daha geniş bir ahlaki ve spiritüel çerçevede değerlendirilmesini sağlamaktadır.

III. Richard oyununda kalan son temel rüya, Clerance ve Richard'inkinden daha alegorik bir rüya olan Lord Stanley'nin rüyasıdır. Bu rüya Stanley ve Hasting bağlamında farklı yönlerden değerlendirilebileceği gibi rüyaların aynı anda doğal ve doğaüstü olarak değerlendirildiği Shakespeare döneminin ikircikli bakış açısının bir sembolü niteliğindedir. III. Perde II.Sahne'de Stanley Hastings'e bir haberci göndererek rüyasında bir yaban domuzu amblemi gördüğünü haber verir:

\footnotetext{
“HABERCI:

Size haber vermemi istedi, bu gece düşünde,

Bir yaban domuzu tolgasını koparıp almış başından.

Ayrıca iki ayrı kurulun toplanacağını haber vermemi istedi;

Birinde alınacak karar,
}

${ }^{48}$ William Shakespeare, a.g.e., s.166. 
Sizin ve kendisinin mahvına neden olacakmış:

Bu yüzden siz efendimizin kararını bekliyor...

Soruyor size, bu görünen tehlikeden kaçmak için,

Derhal atlara atlayıp onunla birlikte,

Son hizla kuzeye gitmek ister miydiniz diye.

HASTINGS

Git efendi, dön lorduna ve söyle ona:

Korkmasin ayrı kurullardan;

Zaten birinde biz ikimiz olacağız,

Diğerinde ise yakın dostum Catesby;

Benim mutlaka bilgim olur

Kurullarda tartışılacak konulardan.

Söyle ona, korkuları boş ve yersiz;

Düşlerine gelince: Şaştım doğrusu,

Nasıl böyle çocukça ciddiye almış,

Sıkıntılı bir gecenin azizliklerini.

Hiç sanmıyorum domuzun saldıracağını;

Üstelik domuz üzerimize gelmeden kaçmak,

Dikkati üstümüze çeker

Ve domuz işte o zaman saldırabilir.

Git efendine söyle, kalkıp bana gelsin;

Birlikte gidelim Kale'ye,

Nasılsa görürüz orada domuzun bize nasıl davranacağını" 49 (Shakespeare, 2010, s.8384)

\section{Sonuç}

İnsan ve insan yaşamı üzerinde güçlü etkilere sahip olan rüyanın, edebiyata ve sanata yansıması şaşırtıcı değildir. Rüya, görsel sanatlardan yazın dünyasının farklı alanlarına kadar, sanatın pek çok dalı ile de yakın etkileşim halindedir. Gerek Antik Çă̆'da gerek Orta Çağ'da gerekse günümüzde düşünürler ve bilim insanları, rüyalara dair fikirler yürüterek, çeşitli kuramlar oluşturmuşlardır. Ancak bu kuramlar, rüyaları yalnızca kendi başlarına bütünüyle anlamlı kılmaya yetmemiştir.

${ }^{49}$ William Shakespeare, a.g.e., s.83-84. 
Rüyaların anlaşılması için, yorumlanmayla desteklenmeye ihtiyaç olduğu noktasında pek çok araştırmacı uzlaşmıştır. Rüya, sanatçılara ve bilim insanlarına doğrudan ya da dolaylı ilham kaynağı olarak yaratıcılığı besler. Sanatçı için rüya, sanatı besleyen sıra dışı bir rehber gibidir.

Shakespeare III.Richard oyununu şekillendirirken dönemin rüyaya bakış açısının ikileminde kalmış; rüyanın doğal bir fenomen ya da doğaüstü bir güç olduğu konusundaki kararsızlığını oyuna yansıtmıştır. Shakespeare; Erken Modern dönemde rüyaların psikofizyolojik mi yoksa doğaüstü mi olduğuna dair yaşanan belirsizliği kullanarak rüya simgelerini kendi metafizik ve materyal perspektifine ve deneyimi içerisinde değerlendirmektedir. Rüyalar; oyun boyunca gerçekleşen olaylara yorum yapmayı kolaylaştıran unsurlar olmasının yanı sıra, karakterlerin eylemlerinin ruhsal açıdan algılanmasına olanak sağlayan güçlü semboller olarak çözümlenebilmektedir.

Shakespeare kendi oyununda daha büyük dramatik bir etki yaratmak için rüyayı görselleştirmeyi tercih etmiştir. Kaynaklarından yola çıkarak Richard ve Richmond karakterleri arasındaki kontrastı derinleştirmek için Richmond'un rüyasını uzatmayı tercih etmiştir. Shakespeare'in bu kısmı yeniden yazması hem karakterleri hem de seyircileri için önemli anların iç görüsünü yansıtmak adına kasten uyarlanmıştır. Sonuçların Edward Hall'ın Union of the Two Noble and Illustrate Famelies of Lancastre and Yorke (1548) eserinden ve The Mirror for Magistrates (1559)'den ya da anonim eser The True Tragedy of Richard III (1588-92? / Bask1 Y1lı: 1594) gibi kaynak eserlerden çıkarıldığı ama Shakespeare tarafından radikal bir biçimde değişikliğe uğratıldı̆̆ı aşikardır.

III. Richard oyununda rüyalar güçlü fizyopsikolojik anlamlar da taşımakla birlikte metafizik müdahalelerden ziyade, öz yıkımı da içeren insan eylemlerinin altını çizerler. Shakespeare'in III. Richard oyunundaki rüyaları farklı rüya yaklaşımlarına uygun olarak sunması, rüyaların keskin bir kategorileştirme altında değerlendirilmesini engellemekte ve karakterlerin trajik deneyimlerinin karmaşıklığına önemli ölçüde katkıda bulunmaktadır.

Sonuç olarak, III. Richard oyununda rüya meydana gelen içsel ve dişsal trajediyi kapsar. Sahne üzerinde karakterleri, sahne dışında ise seyirciye Richard, Clarance ve müttefikleri tarafından yaratılan ve giderek artan korkutucu atmosferi yansıtır. III. Richard oyununda rüyalar; karakterlerin hırslarını, işledikleri suçları ve günahlarını büyüterek oyunun odak noktasını insanların seçim yapma ve bu seçimleri yaşam içerisinde uygulama kapasitesine doğru yöneltmektedir. Shakespeare'in ardından özellikle Sürrealizm ile birlikte sanat dünyasında yerini sağlamlaştıran rüya kavramı tiyatro sahnesinde de iyice belirmeye başlar. Antonin Artaud, Pierre-Albert Birot gibi Sürrealistler de rüyalardan faydalanmayı sürdürerek populer bir dramatik unsur haline getireceklerdir. 


\section{KAYNAKÇA}

Aesychylus. (1991). The Persians, Trans. And Ed. Bristol: Classical Press.

Bullough, G. (1957) Narrative and Dramatic Sources of Shakespeare,Volume 3. London: Routledge and Kegan Paul.

Burrow, C. (2013). Shakespeare and Classical Antiquity, Oxford: University Press.

Daldis, A. (1975). The Interpretation of Dreams: Oneirocritica, Trans. R.J. White, Noyes Press.

Du Laurens, A. (1599). A Discourse of the Preservation of the Sight, Trans. Richard Surphlet, London: Felix Kingston for Ralph Jacson.

Harris, W. (2009). Dreams and Experience in Classical Antiquity, Cambridge: Harvard University Press.

Hill, T. (1576). The Most Pleasaunte Arte of the Interpretacion of Dreames, Thomas Marsh, 1576, A2r - D7r.

Holland, P. (1999). 'The Interpreation of Dreams in the Renaissance' Reading Dreams: The Interpretation of Dreams from Chaucer to Shakespeare, Ed. Peter Brown, London: Oxford..

Macrobius (1952). Commentary On The Dream of Scibio, Trans. And Ed. W.H.Stahl, New York: Columbia University Press.

Marjorie, G. (1974). Garber, Dream in Shakespeare: From Metaphor to Metamorphosis. New Heaven: Yale University Press.

McDonald, R. (2002). 'The Language of Tragedy', The Cambridge Companion to Shakespearean Tragedy, Cambridge: University Press.

Parman, S. (1991). Dream and Culture: An Anthropological Study of the Western Intellectual Tradition. New York: Praeger.

Philips, H. ve Havely N. (1997). Chaucer's Dream Poetry, London-New York: Longman.

Presson, R. (1967). Two Types of Dreams in Elizabethan Drama, and Their Heritage:

Somnium Animale and the Prick-of-Conscience, Studies in English Literature. Volume 7.

No:2, Spring, 239-256.

Scot, R. (1584). The Discoverie of Witchcraft, Being A Reprint of the First edition Published in ed.Brinsley Nicholson, Elliot Stock, London.

Shakespeare, W. (2008). Richard III, ed. John Jowett, Oxford: Oxford University Press.

Shakespeare, W. (2010). III. Richard, Çev. Özdemir Nutku, İstanbul: İş Bankası Kültür Yayınları.

Shaw, J. (2006). Miracles in Enlightment England, New Heaven: Yale University Press.

Stephan G. (2001). Hamlet in Purgatory, Princeton: University Press.

Walsham, A. (1999). Providence in Early Modern England, Oxford: Oxford University.

Weidhorn, M. (1970). Dreams in Seventeenth-Century English Literature, Paris: Mounton\&Co.

Wright, T. (1604). The Passions Of The Minde in General, Valentine Simmes and Adam Islip for for Walter Burre and Thomas Thorpe, London, Mühür Flr. 